\title{
Environmental Management at Pondok Pesantren An- Nur 2 Al Murtadlo Malang Regency with the Implementation of the Eco-Pesantren Program
}

\author{
Fityatul Mila' ${ }^{1,}$ Bagyo Yanuwiadi ${ }^{1}$ Amin Setyo Laksono ${ }^{1}$ \\ ${ }^{\mathbf{1}}$ Department of Biology, Faculty of Mathematics and Natural Sciences, Brawijaya University Malang \\ DOI: 10.29322/IJSRP.11.08.2021.p11626 \\ http://dx.doi.org/10.29322/IJSRP.11.08.2021.p11626
}

\begin{abstract}
Environmental conservation in Islamic boarding schools is very important. One of the efforts to conserve the environment is by building a caring attitude towards the environment. The potential environmental care attitude was applied through the Islamic approach (Ecoteology) in Islamic boarding schools. One of the Islamic boarding schools in the Malang Regency that has the potential to implement Eco-Islamic boarding schools was An-Nur 2 Islamic boarding school in Bululawang, Malang Regency. The socioreligious approach was expected to foster awareness of the students and the surrounding community towards the environment. This study aimed to determine the implementation of Eco-Islamic boarding schools in An-Nur 2 Islamic boarding school towards environmental care and to provide policy solutions for increasing environmental awareness. This research was a case study research using a qualitative descriptive method. The data collection technique was done by using the data triangulation technique (observation, interview, and questionnaire). The results of observations and interviews were analyzed descriptively, while the questionnaire was analyzed quantitatively. Based on the criteria for measuring attitudes, a value of $>60 \%-96.2 \%$ was obtained and a policy solution was to build an environmental care attitude by applying the constructing model of environmental care attitude with eco-pesantren. The Eco-pesantren program had the potential to build a caring attitude towards the environment so that environmental sustainability could be maintained continuously.
\end{abstract}

Index Terms- Environmental management, Environmental education, Eco-pesantren, Islamic boarding schools,

\section{INTRODUCTION}

Environmental problems continue to characterize human life today, such as global warming, water pollution, forest Edestruction, water pollution, the spread of viruses, and diseases. Along with advances in science and technology, several parties are trying to prevent environmental problems that will occur as well as to improve ongoing environmental problems. Various ways are attempted by the government, social institutions, and individuals such as the establishment of policies regarding the environment, movements as a form of concern for the environment. One of these efforts is to apply the Ecopesantren concept.

The eco-pesantren concept was launched by the Ministry of Environment and Forestry. The concept of eco-pesantren comes from two words Eco (eco) and pesantren, each of which has a different definition. "Eco" is taken from the word (ecology) which is a term that is closely related to the environment. Meanwhile, pesantren is a definition that is generally understood as a typical educational institution in Indonesia that teaches Islamic sciences. Thus, Eco-pesantren means an Islamic educational institution that is concerned with environmentally responsive activities. Harper (2008) states that a belief about thoughts and actions that connect religion and the environment is called eco-theology or sometimes called ecospritualism. Islamic boarding schools have an important and strategic role in the protection and management of the environment. This can be seen from several things that make it an Islamic religious institution that holds the most important control in social order and relationships in human life. Islamic boarding schools are traditional Islamic educational institutions to understand, appreciate and practice the teachings of Islam by emphasizing the importance of Islamic morals as guidelines for daily life in society. Abdillah (2014) states that Islamic boarding schools are the oldest educational institutions in Indonesia, which existed before the birth of the modern education system. Pesantren are non-formal educational institutions that are very close to the community and even become part of the community itself. This institution has long been a reference, both in the educational, social, and cultural development of the local community. 
The large role of pesantren in people's lives has proven to be effective as agents of change in the success of various development programs. Besides, pesantren can also be said to be social institutions because pesantren are considered capable of providing social change to the people around them. Ashtankar (2016) states that the best way to protect the environment from destruction and to improve its condition is by reviving an understanding that has been forgotten, namely referring back to the teachings and instructions of divine religions and reviewing and re-adjusting the culture regarding the application of modern technology. in using natural resources appropriately. One of the Islamic boarding schools that has the potential to apply the eco-pesantren concept (pesantren that cares for the environment) is the An-Nur 2 Al Murtadlo Islamic Boarding School located in Bululawang District, Malang Regency. Some of the results of the movement from the An-Nur 2 Al Murtadlo Islamic boarding school were planting trees in areas prone to landslides and around the cottage environment.

In carrying out each of its activities, Pondok Pesantren An-Nur 2 Al Murtadlo mobilizes all its students to participate directly in every activity related to the environment. This has led to research on increasing environmental awareness through the Eco-pesantren program at the An-Nur 2 Al Murtadlo Islamic boarding school, Malang Regency. The results of this study are expected to be used as a reference for related parties to foster a caring attitude towards the environment especially for Islamic boarding schools in Malang Regency. This study aims to convey data and information about the programs and movements of the An-Nur 2 Al Murtadlo Islamic boarding school in caring for the environment in Malang Regency and Malang Raya in general.

\section{RESEARCH ELABORATIONS}

\section{A. Time and Place of Research}

The research was conducted for 3 months, from October to December 2020. The research activity was carried out at the An-Nur 2 Al Murtadlo Islamic Boarding School, Bululawang District, Malang Regency.

\section{B. Research Tools and Objects}

The tools used in this study were a laptop, GPS, camera, and research questionnaire.

The object of research was the community of the An-Nur 2 Al Murtadlo Islamic boarding school.

\section{Sampling}

The data collection for the improvement of environmental care attitudes through the eco-pesantren program at the An-Nur 2 Al Murtadlo Islamic boarding school, Malang Regency, was carried out using descriptive qualitative methods and exploratory field surveys. Exploratory research is a research method that examines and reveals something from the field as findings that can be used to construct models and draw conclusions (Messerschmidt, 1995). Given the limitations of research personnel, time, and costs, the samples in this study were the boarding school leaders, the head of the madrasah, the madrasah employees, the ustadz / teachers, and some students of the An-Nur 2 Al Murtadlo Islamic boarding school.

\section{Data collection}

1. Primary Data was obtained through open interviews based on the outline of the questions that have been made and distributing questionnaires to measure students' attitudes towards the environment.

2. Secondary Data was obtained through tracing data and information through reports, which have something to do with this research.

\section{E. Data Analysis}

To get a background on the environmental movement in the An-Nur 2 Al Murtadlo boom, interviews and questionnaires were carried out. So that the data analyzed in this study were qualitative data and quantitative data. According to (Arikuto, 2010: 282), after the data has been collected, they were classified into two groups of data, namely quantitative data in the form of numbers and qualitative data which was written in words or symbols. In this study, to calculate the internal consistency index of the item i-th statement in the questionnaire, the product-moment formula from Karl Pearson was used. According to (Riduwan, 2011: 80). The formula used in the product-moment correlation is as follows: 


$$
r X Y=\frac{n\left(\sum \mathrm{XY}\right)-\left(\sum \mathrm{X}\right) \cdot\left(\sum \mathrm{Y}\right)}{\sqrt{\left\{\mathrm{n} \cdot \sum \mathrm{x}^{2}-\left(\sum \mathrm{x}^{2}\right)\right\} \cdot\left\{n \cdot \sum \mathrm{x}^{2}-\left(\sum \mathrm{x}^{2)}\right\}\right.}}
$$

Information:

$\mathrm{rXY}=$ internal consistency index for items

$\mathrm{n}=$ the total number of students who were given the questionnaire

$\mathrm{X}=$ Score for item

$\mathrm{Y}=$ total score

\section{RESULTS}

\section{A. General Portrait of Research Locations}

Pondok Pesantren An-Nur 2 Al-Murtadlo is administratively located on Raya Krebet Senggrong No.8, Demano Jaya, Krebet, Bululawang, Malang, East Java 65171. Annur 2 Al-Murtadlo Islamic boarding school as a salaf pesantren committed to environmental management and culture good ecology, which had not been done by many salaf pesantren in general.

\section{B. The indicators set in realizing Eco-boarding schools.}

1. Development of environmentally friendly Islamic boarding school policies. The development of Islamic boarding school policies needed to make this happen is vision and mission of an environmentally friendly Islamic boarding school, developing environmental learning, increasing the human resource capacity (HR) of Islamic boarding schools in the environmental sector, efforts to conserve natural resources (SDA), supporting the realization of clean and healthy Islamic boarding schools, allocating and using funds for activities related to the environment.

2. Islamic-based environmental curriculum development. The delivery of environmental material to students can be done through an integrated and integrated curriculum or separate subjects. Various learning models and learning methods are used to provide students with an understanding of the environment associated with daily routines. The development of an environment-based curriculum can be achieved by the following: developing an integrated learning model, extracting and developing material about the environment in society, developing Islamic environment-based learning methods, developing curricular activities to increase students' knowledge and awareness about the environment, the experience of Islamic teachings about the environment in EcoPesantren activities.

3. Development of extra-curricular activities based on natural tadabbur To realize an environmentally friendly Islamic boarding school, boarding school residents need to be involved in various environmental learning activities. Islamic boarding schools also need to involve the surrounding community in carrying out various extra-curricular activities at the Islamic boarding schools, including holding natural tadabbur activities, taking an active role in environmental action activities carried out by various parties, building networks and partnerships with related institutions, initiating the development of environmental education in Islamic boarding school.

4. Development and or management of supporting facilities and infrastructure for Islamic boarding schools. To realize Eco-Islamic boarding schools, it is necessary to support facilities and infrastructure that reflect environmental management efforts, including the development of Islamic boarding school supporting facilities for environmental education, improving the quality of environmental management inside and outside the boarding school, saving resources. nature (electricity, water, paper), improving the quality of halal and healthy food services, developing a waste management system, utilizing land with environmentally friendly activities, managing sanitation and sanitation that are clean and healthy, and designing environmentally friendly physical development.

\section{Pesantren and the Environmental Movement based on Eco-pesantren}

Environmental preservation in Islamic boarding schools is actualized through Islamic teachings, along with the warmth of environmental problems and various social problems, pesantren strives to present the concept of Islamic teachings in maintaining the environment so that it remains in balance. Some of the movements in the environmental sector starting from the An-Nur 2 Islamic boarding school to the community around the Islamic boarding school include:

1. There are a Vision and Mission that is environmentally friendly

2. Increase the capacity of human resources (HR) in the environmental sector

3. Maintain cleanliness in the pesantren environment independently by the students.

4. Integrated learning model.

5. Islamic environment-based learning methods 
6. Conducting environmental socialization through recitation in the pesantren environment and the surrounding community, interactive dialogue about the environment, and Friday sermons on the theme of environmental preservation.

7. Often organizes natural tadabbur activities such as planting trees in barren areas, cleaning up rubbish at tourist sites, and rehabilitating forests.

8. Take an active role in environmental action activities carried out by various parties.

9. Build partnerships with institutions related to the environment.

10. Making the facilities and infrastructure of Islamic boarding schools environmental education.

11. Active inside and outside the boarding school in managing the environment and natural resources (SDA).

12. Carry out waste management in Islamic boarding schools.

13. Conservation of plants through the creation of a mini forest boarding school.

\section{Exemplary Attitude and concern for the environment}

The efforts to conserve environmental functions carried out by the An-Nur Islamic boarding school had been going on for a long time but had not yet received attention from the government or the community. Environmental conservation in Islamic boarding schools was actualized through Islamic teachings, along with the warmth of environmental problems and various social problems, pesantren strived to present the concept of Islamic teachings in maintaining the environment so that it remained in balance. Pesantren is a subculture was an educational and social institution that embodied the compulsory education process in the development of the national education system, because historically,

Based on the statements above, it means that pesantren could not be separated from social life in its participation in building the nation and state. The dynamics of the pesantren as agents of change (agents of change) could be seen in the pesantren environment and the surrounding community where the pesantren is domiciled, both in solving social problems to environmental problems as a place to carry out life. One of the pesantren's guidelines in protecting the environment is a mandate given by God to humans in protecting the earth as a caliph (God's representative) to keep it in balance. The activities of the pesantren are more on matters related to religion, but along with changing times and changing needs, many kyai come from the pesantren,

Exemplary Attitude is an activity in the form of daily behavior that is not programmed because it is carried out without knowing the boundaries of space and time. This example is the behavior and attitude of teachers and education personnel and students in giving examples through good actions so that they are expected to become role models for other students (Wiyani, 2012: 140). Efforts in fostering a friendly attitude towards the environment can be carried out by the following methods: Teaching, exemplary, habituation, reflection (Ministry of Environment, 2011: 26-27).

The caring attitude of the students at Pondok Pesantren An-Nur 2 is visible in their routine cleanliness activities, this activity is carried out every day before entering the study room. This activity is carried out as a mandatory activity so that it becomes an example of a habitual attitude. Exemplary attitudes and student concern for the environment were assessed descriptively through a Likert scale questionnaire which had quantified the answer choices (Halid, 2014).

Based on the results of the data analysis, the attitudes of students towards the environment in an environmentally friendly or unfriendly context are as follows. The analysis result shows that the figure is $60 \%$ to $96.2 \%$. Based on the numerical criteria on the attitude measurement scale that:

$\leq 20 \%=$ Very low

$>20-40 \%=$ Low

$>40-60 \%=$ Enough

$>60-80 \%=$ High

$>80-100 \%=$ Very high (Riduwan and Sunarto, 2011)

Based on the numerical criteria on the attitude measurement scale, the attitude of the students in paying attention to the environment in Pondok Pesantren An-Nur 2 was quite high to very high. This was possible because of the knowledge obtained through learning and the involvement of students in protecting the environment so that it responded to the conditions of the surrounding environment. To find out the number of students who had friendly and unfriendly attitudes towards the environment, based on the results of data analysis in the research questionnaire, it can be seen in the following diagram. 


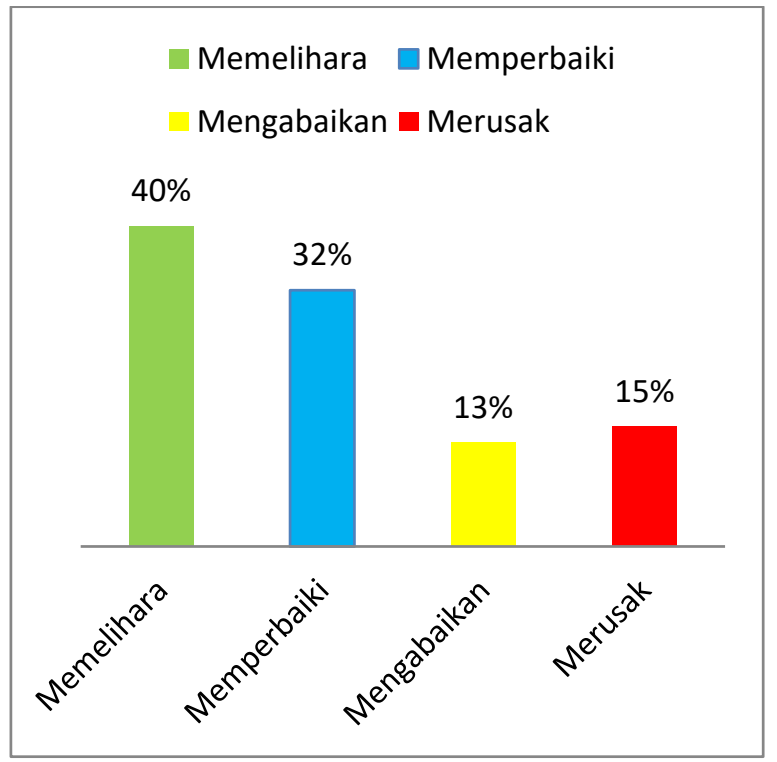

Figure 1. Attitudes Toward the Environment

The number of respondents who had a nurturing attitude is as much as $40 \%$, a repair attitude $32 \%$, an attitude of ignoring $13 \%$, and a destructive attitude $15 \%$. An environmentally friendly attitude if it was combined between an attitude of maintaining and repairing will amount to $72 \%$, and an environmentally unfriendly attitude, when combined between an attitude of neglecting and damaging it, will amount to $28 \%$. The high percentage of students at the An-Nur 2 Al-Murtadlo Islamic boarding school in maintaining and improving the environment is possible because of the Kiai's example in environmental activities, the active students in social service activities by planting trees on bare land, giving free tree seeds to the community and scouting activities that do not forget environmental activities.

The difference in the percentage of students in measuring environmentally friendly attitudes (maintaining and repairing) not being environmentally friendly (ignoring and damaging) at the An-Nur 2 Al-Murtadlo Islamic boarding school, is back to the exemplary activities and patterns taught in the pesantren. The more the introduction of the environment and the program of activities that care for the environment, enabling the high attitudes of students to be friendly to the environment, conversely, the lack of attention of the pesantren to the environment or program of activities caring for the environment, it will allow a small percentage of students to be friendly to the environment due to a lack of knowledge and experience.

The results of the attitude assessment at the An-Nur 2 Al-Murtadlo Islamic Boarding School were interpreted as high or most of the students were environmentally friendly, the high attitudes of attention to the environment at the An-Nur 2 Al-Murtadlo Islamic Boarding School were due to exemplary, relevance, and synergy between strengthened wisdom values. with the teachings of Islam in the pesantren environment, namely as a caliph in carrying out the mandate of Allah SWT. Based on the results of the assessment of pesantren attitudes and actions in the environmental movement, the attitude of concern for the environment in the An-Nur 2 AlMurtadlo Islamic boarding school was closer to the deep ecological attitude. In terms of meaning, a deep ecology is a holistic approach to dealing with earth's problems, by combining thoughts, feelings, spirituality, and actions, so that we need to have a deeper connection with life. So, ecology was not just seeing something outside ourselves, but we were part of it and have a role in it (Tasdiyanto, 2011: 15).

\section{E. The Ecological Cultural Relevance of An-Nur 2 Al Murtadlo Islamic Boarding School with Islamic Values in the Environment}

a) Pesantren An-Nur $2 \mathrm{Al}$ Murtadlo had a simple philosophy, namely santri ben krasan (students so that they feel at home in the Islamic boarding school) which was actualized in the form of a tourist boarding school.

b) Like a tourist spot, the Annur 2 Al-Murtadlo Islamic Boarding School developed a beautiful, clean, green, and pleasant Islamic boarding school environment. Supported by the construction of land that was hilly and flowed by a river that divided the pesantren 
environment, making the santri dormitory building looks like it was on a hill and at the bottom of a valley. Not to mention the existence of a garden, a fountain, a gazebo, and a mini zoo, making this boarding school a place very comfortable.

c) One of the actions taken to support a tourist boarding school was waste management or waste that had met minimum standards, namely the 3R program, namely Reduce (reduce use), Reuse (reuse), and Recycle (recycling).

d) The management of the pesantren environment used the principle of roan (community service), a form of commitment that the pesantren was common property, from the students, by the santri, and for the santri. This principle is used as the basis for shaping the character of the santri, including the character of ecological piety. The practice of roan (community service) was carried out every day after dawn recitation for a maximum of fifteen minutes and every Friday morning starting at 07.30-10.00 which was carried out by Pesantren residents namely Kiayi / caregivers, Ustadz and Santri. The roan (community service) objects were all pesantren facilities starting from dormitories, schools, mosques, offices, parks, gardens, gazebos, roads, rivers, bathrooms, and others.

e) This pesantren also implemented smoke-free provisions, which were used as a measure of the level of air pollution in the pesantren environment.

f) The aspect of institutional resilience, this pesantren was experiencing growth as evidenced by the existence of institutional development programs in the fields of formal and informal education, namely Madrasah Ibtidaiyah, Madrasah Tsanawiyah Level, Madrasah Aliyah, Junior High Schools, and Senior High Schools. Managing Informal institutions, Madrasah Diniyah, Yellow Book High School, and Tahfidz. In the field of economic resilience, this pesantren has developed various forms of business units, currently having An-Nur gas stations, Minimarket, Telecommunication services, Motorcycle repair shops, Agriculture, bottled mineral water, transportation services, mini banks, guess houses, and catfish cultivation.

Judging from the local wisdom possessed by the An-Nur 2 Al Murtadlo Islamic boarding school, it was very relevant (not contradictory) to the teachings of Islam that are present among residents of the An-Nur 2 Al Murtadlo Islamic boarding school. Religion is the right thing to provide a moral orientation for religious believers to find a basic orientation of life in religion. However, religion also requires ethical skills so that it can provide orientation, not just indoctrination. Concerning this theory, and art in religious teachings must be able to provide rational evidence behind orders and prohibitions (Setyono, 2011: 62)

The relevance of Islamic teachings to local wisdom on the concept of "cosmology", could be seen in the expression of the concept of three relations in Islamic teachings, namely, Hablumminallah (human relations with their gods), hablumminannas (human relations with others), and natural hablumminal (human relations with their environment). Some of the commands in protecting the environment and prohibitions as well as a description of the rational consequences that will be obtained for people who do not obey them seem to strengthen the religious orientation of the culture of the residents of the pondok and especially the local community.

The relevance of Islamic teachings in the pesantren environment which is not contradicting local wisdom in the cosmological context in the community will create a mutually sustainable system, namely: Coordination, integration, synergy, and synchronization. Thus the term is shortened by the term KISS.

a) Coordination. With the relevance of Islamic values and local wisdom, the development coordination system does not involve one party but can involve the government, Islamic boarding schools, and local communities.

b) Integration, namely Islamic values, has a close relationship with local wisdom within the pesantren and the surrounding community to strengthen the orientation of community beliefs in religion and maintain local wisdom.

c) Synergy, which is a form of direction and goal that is the same and mutually supportive of local wisdom and Islamic values that are taught with local wisdom.

d) A synchronization is a form of unifying Islamic values taught in Islamic boarding schools with local wisdom values. Given the concept of Islamic teachings above, that the position of man is equal to the universe, at least humans must be able to respect each other (natural hablumminal). thus humans do not feel they have full authority in exploiting Natural Resources (SDA). In addition to the use of natural resources, humans are required to have the responsibility to maintain their sustainability. Because no matter how small the good and the wrongs were done to fellow creatures will undoubtedly be taken into account in the future (Halid, 2014).

\section{CONCLUSION}

Through the eco-pesantren program, Pondok Pesantren An-Nur 2 has carried out a movement to care for the environment starting in the pesantren's environment so that it eventually extends to the surrounding community. Some of the movements that have been carried out based on indicators from the eco-pesantren program are:

This publication is licensed under Creative Commons Attribution CC BY.

http://dx.doi.org/10.29322/IJSRP.11.08.2021.p11626

www.ijsrp.org 
1. The vision and mission of an environmentally friendly Islamic boarding school so that the rules and regulations in the An-Nur $2 \mathrm{Al}$ Murtadlo Islamic boarding school promote a caring attitude towards the environment.

2. Increase the capacity of human resources (HR) through madrasah activities such as the integrated madrasah curriculum.

3. The movement to care for the environment has been done a lot as a form of concern for the environment.

4. Making the facilities and infrastructure of Islamic boarding schools environmental education. The environmental movement carried out at the An-Nur $2 \mathrm{Al}$ Murtadlo Islamic boarding school, Malang Regency, is an environmental movement motivated by religious beliefs and knowledge in fulfilling duties and obligations as being created by Allah SWT (caliph) on earth.

\section{REFERENCES}

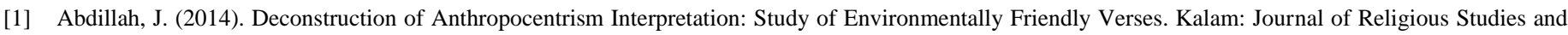
Islamic Thought, vol 8, no 1, pp. 65-68

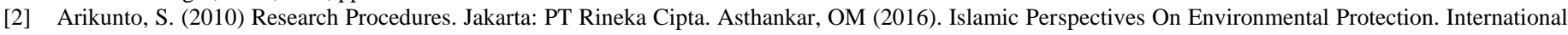
Journal Of Applied Research, vol 2, no 1, pp. 438-441

[3] Budiwanti, E. (2000). Islam Sasak, Yogyakarta, LKiS

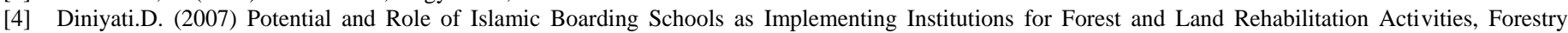
Research Centers, Ciamis.

[5] Harper, CL (2008). Religion And Environmentalism. Journal Of Religion And Society, pp. 5-26 ISSN: $1941-8450$.

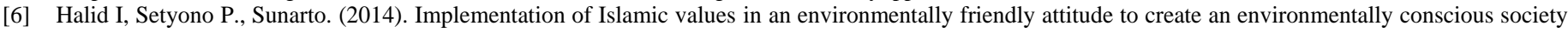
through the Islamic boarding school movement. Journal of Ecosciences, vol 6, no 1.

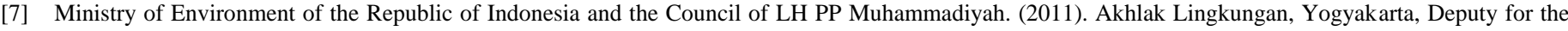
Community of Environment and Community Empowerment, Ministry of Environment and LH.PP Muhammadiyah council.

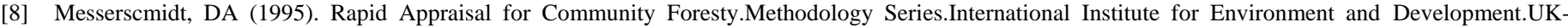
London. Riduwan and Sunarto. 2011. Introduction to Statistics. Bandung: Alfabeta

[9] Rohadi, T. (2011). Environmental Culture. Yogyakarta: Ecologia Press.

[10] Setyono, P. (2008). Horizons Understanding the Environment. Solo. UNS Press.

[11] Suharto, Baboons. (2011). From the Islamic Boarding School for the Ummat of Surabaya: Imtiyaz.

[12] Wiyani.NA (2012), Management of Character Education. Yogyakarta.PT. Insan Madani Library.

\section{AUTHORS}

First Author - Fityatul Mila, Graduate students of Biology, Deprtment of Biology, Faculty of Mathematics and Natural Sciences, Brawijaya University (email: milafidyatul@student.ub.ac.id)

Second Author - Bagyo Yanuwiadi, Professor at Department of Biology, Faculty of Mathematics and Natural Sciences, Brawijaya University (email: yanuwiadi@ub.ac.id)

Third Author - Amin Setyo Leksono, Professor at Department of Biology, Faculty of Mthematics and Natural Sciences, Brawijaya University (email: $\underline{\text { amin28@ub.ac.id) }}$

Correspondence Author - Amin Setyo Leksono, email: amin28@ub.ac.id or aminleksono72@gmail.com contact number : +628121737103 